\title{
PUBLIC RELATIONS FOR MARKETING PROFESSIONALS
}




\section{STUDIES IN PUBLIC RELATIONS}

Series Editor: Norman A. Hart, MSc FIPR FCIM FCAM

The Studies in Public Relations series of books is designed to present public relations in its new and developing role as a strategic function contributing to the achieving and enhancement of business objectives. It represents a 'second generation' of textbooks which will move from the hitherto concentration on press relations into a wider corporate role.

The series is edited by Norman Hart, a well-known international writer and speaker on all aspects of public relations and marketing communications. Author of many books on various communications subjects, he is a Fellow of the Institute of Public Relations, and was the first Professor of Public Relations in the United Kingdom. Norman is a past Chairman of the International Public Relations Foundation. 


\section{Public relations for marketing professionals}

Roger Haywood

Foreword by Steve Cuthbert 
All rights reserved. No reproduction, copy or transmission of this publication may be made without written permission.

No paragraph of this publication may be reproduced, copied or transmitted save with written permission or in accordance with the provisions of the Copyright, Designs and Patents Act 1988, or under the terms of any licence permitting limited copying issued by the Copyright Licensing Agency, 90 Tottenham Court Road, London W1T 4LP.

Any person who does any unauthorised act in relation to this publication may be liable to criminal prosecution and civil claims for damages.

The author has asserted his right to be identified as the author of this work in accordance with the Copyright, Designs and Patents Act 1988.

Published by

PALGRAVE

Houndmills, Basingstoke, Hampshire RG21 6XS and

175 Fifth Avenue, New York, N. Y. 10010

Companies and representatives throughout the world

PALGRAVE is the new global academic imprint of St. Martin's Press LLC Scholarly and Reference Division and Palgrave Publishers Ltd (formerly Macmillan Press Ltd).

\section{ISBN 978-0-333-68477-1 ISBN 978-1-349-14365-8 (eBook)}

DOI 10.1007/978-1-349-14365-8

This book is printed on paper suitable for recycling and made from fully managed and sustained forest sources.

A catalogue record for this book is available from the British Library.

$\begin{array}{rrrrrr}10 & 9 & 8 & 7 & 6 & 5 \\ 07 & 06 & 05 & 04 & 03 & 02\end{array}$

Copy-edited and typeset by Povey-Edmondson Tavistock and Rochdale, England 


\section{Contents}

Foreword by Steve Cutbbert

vii

Acknowledgements

viii

1 Marketing: what business is all about The marketing perspective

2 Public relations: the management of reputation Some public relations fundamentals

3 Managing public relations

The policies, the people, the planning

4 Communications and issues audits

The objective base for planning

5 Public relations budget and resources Appointing and handling professionals

6 Public relations direction

Planning and writing the brief

7 Setting performance criteria

Developing and agreeing measurable targets

8 Marketing: the diverse business discipline

Public relations in marketing planning

9 Marketing: the diverse business discipline

Public relations in support of marketing implementation

10 Marketing: international communications

Appendix: Sources of information

Selected bibliography

Index 


\section{Foreword}

Good marketing must mean good communications. Public relations is a vital element in running a successful business yet, too often, what should be a central business discipline is run as if it were all a matter of personal opinion or idiosyncratic judgement. But good public relations should be planned, should be managed and should be appraised. Everyone buying or using public relations services should look at the principles that underpin the craft - and try to develop procedures that produce the maximum benefit and the highest levels of cost effectiveness from the resources and budget that they allocate to this important function. Indeed, as the author of Public relations for marketing professionals argues persuasively, there may be opportunities to improve marketing effectiveness through the wiser allocation of such resources - if the marketers know where and how to allocate these.

Roger Haywood is a rare character in that he has chaired with considerable success both the Chartered Institute of Marketing and the Institute of Public Relations. Though he has written and broadcast extensively on business communications, he is more than a theorist. $\mathrm{He}$ is a pragmatic experienced professional who cuts through jargon to offer practical and useable advice. How many marketing people really know how to recruit winning public relations personnel: or how to get the best people in the consultancy demanding to work on their account: or the six essentials to remember when setting up a media interview: or the unfailing no-cost way to test the value of a news story: or the critical factor to set in place first when a crisis hits the organisation? As with marketing, learning from mistakes can be a bruising and expensive way to develop essential skills.

Most business people need a better understanding of marketing. And many marketing professionals need a better understanding not just of what public relations is but how to manage it. Used effectively, public relations can help build the company reputation as well as protect it when the going gets tough.

STEve Cuthbert

Director General

The Chartered Institute of Marketing

Maidenhead 


\section{- Acknowledgements}

My appreciation goes to my many partners within the Worldcom Group for their suggestions, examples and ideas used throughout this book. It has been a privilege to be part of the Worldcom international partnership; I was fortunate enough to be able to play a part in the formation and development of this remarkable organisation - and, in recent years, to have found associates who have become colleagues and then friends as we have built the organisation from nothing in 1988 into the world's largest partnership of independent consultancies, with 120 offices across the business capitals of the world.

I would also like to thank the many public relations and marketing professionals who have given their time in supplying many of the case studies in this book and who, in many cases, have helped check and constructively amend my copy. I cannot mention each here - but every one is acknowledged in the index. Without their expertise and generosity, this book would not have been possible. Particular appreciation must go to the many members of the Institute of Public Relations, the Chartered Institute of Marketing and The Marketing Society who gave me such support and assistance in the creation of this guide.

I would also like to thank my business partner John Dresser for his unfailing good humour through the trials of preparing this book at a time that we were also developing and building our own business.

But above all, my deepest appreciation must go to my personal partner (as the PC terminology suggests is appropriate these days), my wife Sandra, for tolerating an intolerable other half.

\section{Towards the meritocracy}

Whilst making acknowledgements, let me say that one of the joys of the media, public relations and marketing industries is the impressive capabilities of so many of the people at all levels in the business. Our sectors must be amongst the most egalitarian, where achievement relates most closely to performance. We are not yet a true meritocracy for the ethnic minorities have not yet fully achieved senior representation - but all the opportunities are open. Women are not a minority, but in some businesses it is taking a long time for them to get the recognition they deserve. Probably more of the best professionals at the top of our business are women than in any other industry. So when I use 'he' in this book, it is because it becomes tedious to say 'he or she' every time. Equally, I am resistant to the fudge of putting everything into the plural to disguise the gender. If this approach irritates anyone, I am sorry. I doubt that any of the many talented women I have worked with and for will take offence. 